\title{
Fasies dan Sekitaran Sedimen Formasi Singa di Langkawi, Malaysia
}

(Facies and Sedimentary Environment of Singa Formation of Langkawi, Malaysia)

\author{
Mohamad Hanif Kamal Roslan, Che Aziz Ali* \& Kamal Roslan MoHamed
}

\begin{abstract}
ABSTRAK
Batuan Formasi Singa yang terdiri daripada batu lumpur dominan, berselang lapis dengan batu lodak, batu pasir dan juga sedikit unit konglomerat tertabur secara meluas di kepulauan Langkawi. Formasi Singa boleh dibahagikan kepada sepuluh fasies sedimen dan empat sekutuan fasies. Keputusan kajian menunjukkan Formasi Singa telah terendap di lautan cetek, iaitu di sub-sekitaran luar pesisir, transisi, muka pesisir serta dalam alur. Lautan cetek Lembangan Singa dipengaruhi oleh iklim sejuk kerana terdapat sedimen asalan glasier, iaitu fasies batu lumpur berpebel. Kertas kerja ini akan menjelas dan membincangkan segala aspek sedimentologi formasi batuan ini.
\end{abstract}

Kata kunci: Analisis fasies; Formasi Singa; sedimentologi

\section{ABSTRACT}

Rocks of the Singa Formation are widely distributed in Langkawi. The formation dominantly consists of mudstones interbedded with siltstone, sandstone and conglomerate units. the Singa Formation can be divided into ten types of sedimentary facies and four types of facies association. Based on facies analysis, the Singa Formation is interpreted to have been deposited in offshore, offshore-transition and shoreface environments and also in channel. This shallow marine of the Singa Basin are affected by cold climates, because there are glacial sedimentary deposits namely pebbly mudstone facies. This paper will describe and discuss all aspects of sedimentology for this formation.

Keywords: Facies analysis; sedimentology; Singa Formation

\section{PENDAhUluan}

Kepulauan Langkawi yang menyingkapkan batuan Formasi Singa terletak di barat laut semenanjung Malaysia. Singkapan utama boleh ditemui di pulau-pulau kecil seperti Pulau Ular, Lalang, Selang, Singa Kecil, Singa Besar, Beras Basah, Tepor, Rebak Besar dan Rebak Kecil. Di daratan pulau besar pula singkapan pantai wujud dari Pantai Chenang ke Teluk Baru hingga Kuala Temoyong, singkapan bukit di Temoyong, Batu Asah, sepanjang jalan Kelibang - Kuah dan sekitar Durian Perangi serta Gunung Raya (Rajah 1). Kertas ini memfokuskan kepada aspek sedimentologi batuan Formasi Singa di sekitar Kepulauan Langkawi yang melibatkan pemetaan dan pencirian fasies sedimen untuk menentukan proses yang berlaku semasa pengendapan Formasi Singa.

\section{FORMASI SINGA}

Geologi Formasi Singa telah dikaji oleh beberapa penyelidik terdahulu seperti Ahmad (1973), Gobbett (1973), Jones (1981) dan Stauffer dan Lee (1986). Nama Formasi Singa pertama kali digunakan oleh Jones di dalam peta geologi Pulau Langkawi yang diterbitkan oleh Geological Survey Malaysia pada tahun 1966 merujuk kepada unit selang lapis nipis (batu lumpur hitam, syal berlodak, batu lodak), batu pasir litik dan kuarza yang berusia Devon Akhir hingga Perm Awal. Ahmad (1973) telah membahagikan jujukan batuan Formasi Singa kepada empat ahli iaitu Ahli Rebak, Kentut, Ular dan Selang. Ketebalan keseluruhan batuan Formasi Singa dianggarkan setebal 2100 m (Che Aziz \& Tanot 2011). Taburan batuan Formasi Singa lebih tertumpu di bahagian barat daya kepulauan Langkawi dan mengunjur sehingga di sekitar Gunung Raya dan Pulau Langgun.

Formasi Singa ditafsirkan setara dengan Formasi Kubang Pasu yang tersingkap di Perlis dan utara Kedah (Gobbert 1973; Jones 1981; Ridd 2013) dan Kumpulan Kaeng Krachan di selatan Thailand (Metcalfe 1986; Ridd 2013; Stauffer \& Lee 1986; Tantiwanit et al. 1983; Ueno et al. 2005). Formasi Singa juga boleh disetarakan dengan Formasi Bohorok yang tersingkap di timur Sumatera (Metcalfe 1986, 1984).

\section{FASIES SEDIMEN}

Fasies batuan adalah batuan sedimen yang mempunyai ciri-ciri unit sedimen yang tersendiri seperti litologi, tekstur, struktur dan fitur paleontologi yang lazimnya berubah secara lateral dan menegak dalam jujukan sedimen (Reading 1986; Tucker 2003). Cerapan di lapangan menunjukkan Formasi Singa boleh dibahagikan kepada 10 fasies seperti berikut. 


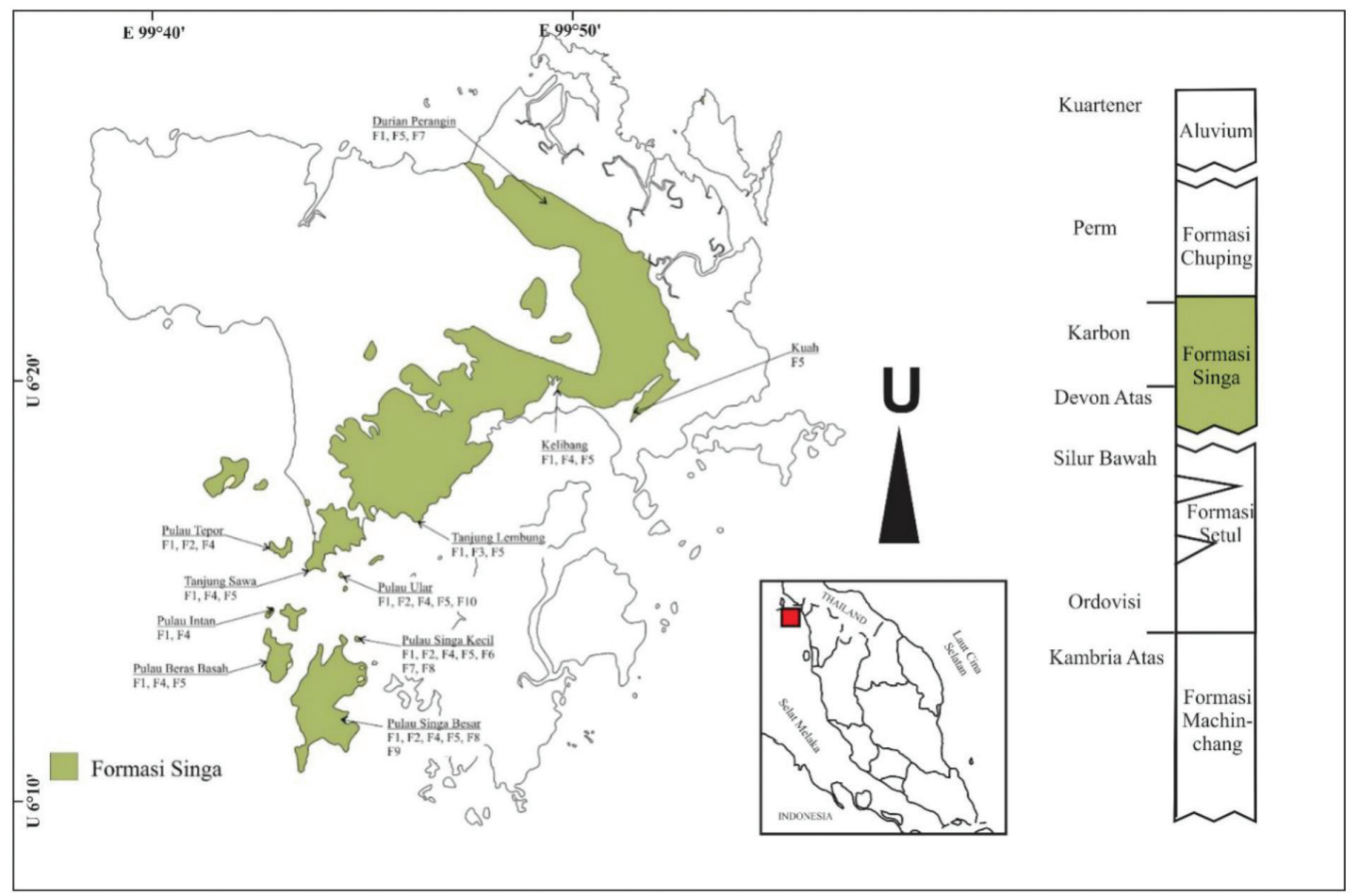

RAJAH 1. Taburan dan hubungan stratigrafi Formasi Singa di kepulauan Langkawi (Diubahsuai daripada Jones 1981)

\section{F1 - FASIES BATU LUMPUR TEBAL}

Fasies ini terdiri daripada batu lumpur berlodak berwarna kelabu gelap dengan ketebalan lapisan antara $40 \mathrm{~cm}$ hingga 4 meter yang kadangkala ternendat. Fosil surih seperti Arenicolites isp., Planolites isp. (Rajah 2(a)), Teichichnus isp. dan Thalassinoides isp. lazim ditemui. Fasies ini tersingkap di kebanyakan tempat di kawasan kajian termasuk di Tanjung Hantu, Tanjung Chengai, Tanjung Lembung, Bukit Malut, Pulau Selang, Pulau Lalang, Pulau Singa Besar, Tanjung Mali dan Taman Helang Perdana.

Tafsiran Pengendapan fasies berlumpur umumnya terjadi melalui proses ampaian di sekitaran yang tenang (Reading 1986). Pengelasan oleh Frey dan Pemberton (1985) menunjukkan Arenicolites isp. selalunya wujud di sekitaran yang bertenaga sederhana hingga tinggi manakala Planolites isp., Teichicnus isp. dan Thalassinoides isp. pula berada pada sekitaran yang lebih tenang dengan arus yang sederhana hingga rendah. Struktur nendatan menunjukkan terdapat pergerakan secara menggelongsor berlaku di kawasan bercerun (Collinson \& Thompson 1982).

\section{F2 - FASIES BATU LUMPUR BERPEBEL}

Fasies ini terdiri daripada batu lumpur berwarna kelabu gelap, berketebalan antara 0.5 hingga $2 \mathrm{~m}$ dan terdapat pebel yang tertabur secara rawak. Kesferaan dan kebulatan bagi setiap pebel adalah sangat berbeza. Pebel bersaiz antara 2 hingga $40 \mathrm{~cm}$ terdiri daripada batu pasir, batu kapur (Rajah 2(b)), kuarzit dan granit. Di sesetengah kawasan, terdapat fosil brakiopod, bryozoa serta fosil surih di dalam fasies ini. Fasies ini boleh dijumpai di Pulau Tepor, Tanjung Mali, Pulau Singa Besar, Pulau Singa Kecil, Pulau Kentut Besar, Pulau Lalang, Pulau Ular, Tanjung Hantu, Tanjung Chengai dan Taman Helang Perdana.

Tafsiran Pengendapan melalui apungan ais di kawasan tenang merupakan proses yang paling sesuai bagi menerangkan kehadiran kepelbagaian jenis, bentuk dan saiz pebel di dalam fasies berlumpur (Mohd Shafeea 2000). Kehadiran fosil jenis brakiopod dan bryozoa dalam fasies ini mencadangkan sekitaran laut cetek yang tenang (Mohd Shafeea 2004, 1997). Mohd Shafeea (2004, 2000, 1996), Stauffer dan Lee (1986) serta Stauffer dan Manjit (1981) bersetuju bahawa proses apungan ais telah memendapkan pebel dalam fasies ini.

\section{F3 - FASIES HETEROLITIK}

Fasies ini terdiri daripada perselangan antara batu pasir dan lumpur dalam satu unit perlapisan (Rajah 2(c)). Fasies ini mengandungi kandungan pasir yang berbeza yang membolehkan fasies ini dibahagikan kepada tiga subfasies iaitu pasir dominan (75-90\% pasir), campuran (50-75\% pasir) dan lumpur dominan (10-50\% pasir). Fasies heterolitik ini boleh dibahagikan kepada tiga iaitu pelapisan flaser (F3a), perlapisan beralun (F3b) dan pelapisan 'lenticular' (F3c). Struktur riak simetri ditemui dalam fasies ini.

Tafsiran Kehadiran dua litologi berbeza yang berselang lapis ini menunjukkan pengendapan berlaku dalam dua 
proses yang berbeza pada fasa yang sama. Antara proses yang memungkinkan pembentukan fasies ini adalah perselangan proses antara pengendapan arus pasang surut dengan pengendapan sedimen terampai semasa air tenang (Klein 1977). Menurut Reineck dan Singh (1975), pelapisan flaser terendap dengan kehadiran arus yang kerap sebelum lapisan nipis lumpur terendap secara ampaian, manakala pelapisan lentikular pula menerima sedimen lumpur secara ampaian lebih kerap dalam sekitaran yang tenang sebelum pasir nipis terendap dengan kehadiran arus. Pelapisan beralun pula menerima sedimen bersaiz lumpur melalui proses ampaian dan sedimen bersaiz pasir dengan kehadiran arus secara sekata dan berulang kali.

\section{F4 - FASIES SELANG LAPIS BATU LUMPUR, BATU LODAK DAN BATU PASIR}

Fasies ini terdiri daripada batu lumpur, batu lodak dan batu pasir yang berselang lapis (Rajah 2(d)). Ketebalan setiap lapisan litologi fasies ini berjulat antara 1 hingga 30 $\mathrm{cm}$. Fasies F4 boleh dibahagikan kepada sub-fasies F4a, F4b dan F4c. Sub-fasies F4a tidak menunjukkan struktur sedimen yang jelas dalam jujukan batuan, Sub-fasies F4b mengandungi struktur fosil surih seperti Arenicolites isp. (Rajah 2(e)), Planolites isp. dan Thalasinoides isp. dan subfasies F4c pula mempunyai struktur nendatan. Fasies ini tertabur secara meluas pada hampir keseluruhan kawasan kajian terutamanya di bahagian barat daya Kepulauan Langkawi.

Tafsiran Fasies ini terbentuk melalui proses dan fasa pengendapan yang berbeza di satu sekitaran yang sama. Pengendapan sedimen bersaiz lumpur lazimnya berlaku secara ampaian dalam sekitaran yang tenang dan sedimen bersaiz lodak serta pasir pula berlaku dalam sekitaran yang berarus. Kehadiran fosil surih mencadangkan persekitaran bertenaga tinggi hingga sederhana (Collinson \& Thompson 1982).

\section{F5 - FASIES BATU PASIR TEBAL}

Fasies ini terdiri daripada batu pasir berbutir halus hingga sederhana dengan ketebalan lapisan berjulat antara $30 \mathrm{~cm}$ hingga 4 meter (Rajah 2(f)). Pada singkapan di Kelibang dan Pulau Lalang dijumpai fosil batang krinoid, brakiopod dan Polypora sp. yang membentuk biostrome. Kebanyakan sampel yang dicerap memperlihatkan bentuk butiran yang bersudut hingga sub-bersudut dan ada juga yang bulat hingga sub-bulat. Fasies ini boleh dijumpai di sekitar Pulau Singa Kecil, Pulau Singa besar, Pulau Ular, Pulau Lalang, Tanjung Lembung, Kelibang dan Kuah.

Tafsiran Batu pasir bersaiz halus hingga sederhana ini ditafsirkan terendap dalam sekitaran berarus yang bertenaga sederhana (Reading 1986). Kehadiran fosil krinoid, brakiopod dan Polypora sp. mencadangkan persekitaran laut cetek (Mohd Shafeea 1997).

\section{F6 - FASIES BATU PASIR TERGRED}

Fasies batu pasir tergred ini terdiri daripada lapisan batu pasir yang mempunyai ketebalan dari 0.2-0.5 m dan memperlihatkan struktur tergred secara menghalus ke atas. Pada bahagian paling atas fasies ini, butiran bersaiz lumpur boleh diperhatikan. Tiada sempadan yang jelas dapat diperhatikan antara butiran yang berlainan saiz ini. Fasies ini boleh dijumpai di Tanjung Mali dan Pulau Singa Besar.

Tafsiran Pelapisan batu pasir tergred selalunya terbentuk disebabkan oleh aliran turbidit di kawasan yang bercerun (Reading 1986). Selain terbentuk pada sekitaran yang bercerun, arus turbidit juga boleh dicetuskan oleh ribut di sekitaran laut cetek (Pattison et al. 2007; Wheatcroft 2000) dan tsunami (Weiss \& Bahlburg 2006).

\section{F7 - FASIES BATU PASIR BERPELAPISAN SILANG}

Fasies Batu Pasir Berpelapisan Silang terdiri daripada lapisan batu pasir berbutir halus hingga kasar dan memperlihatkan struktur lapisan silang yang sangat jelas. Tebal lapisan fasies ini ialah sekitar $30 \mathrm{~cm}$. Fosil dan struktur fosil surih tidak ditemui dalam fasies ini. Fasies ini dijumpai di bahagian selatan Pulau Ular dan Pulau Beras Basah dan Pulau Singa Besar.

Tafsiran Batu pasir berpelapisan silang kebanyakannya terbentuk akibat migrasi gumuk atau riakmega oleh arus seretan yang bertenaga tinggi. Struktur pelapisan silang ini juga boleh terbentuk dalam alur sungai, terutama pada sungai bersirat, dalam palung besar dan di tepi pantai yang mempunyai regim tenaga tinggi (Nichols 2009).

\section{F8 - FASIES BATU PASIR BERLAMINASI SELARI}

Fasies ini terdiri daripada batu pasir berbutir halus hingga sederhana dengan struktur laminasi selari yang jelas (Rajah 2(g)). Ketebalan lapisan berjulat antara $30 \mathrm{~cm}$ hingga 1 meter. Pada sesetengah lapisan batu pasir ini terdapat struktur kesan kerukan boleh diperhatikan pada bahagian bawah lapisan. Fasies ini dijumpai pada singkapan di air terjun Durian Perangin dan Pulau Singa Kecil. Di Durian Perangin terdapat sedikit batuan berisihan buruk pada fasies ini. Struktur lapisan tergred berskala mikro turut boleh diperhatikan dalam sampel tersebut.

Tafsiran Fasies ini ditafsirkan terendap dalam sekitaran arus yang bertenaga sangat tinggi. Arus yang kuat ini akan memusnahkan pelapisan yang beralun dan membentuk lapisan planar (Nichols 2009).

\section{F9 - FASIES BATU PASIR BERKLASTA}

Fasies ini terdiri daripada lapisan batu pasir kasar hingga sederhana dengan ketebalan berjulat antara 0.5 hingga $1 \mathrm{~m}$. Di dalam lapisan batu pasir ini terdapat klasta batu lumpur berbentuk bersegi, bersaiz 5 hingga $15 \mathrm{~cm}$ dan tertabur secara rawak terutamanya di bahagian bawah lapisan batu pasir (Rajah 2(h)). Fasies ini memperlihatkan struktur alur 

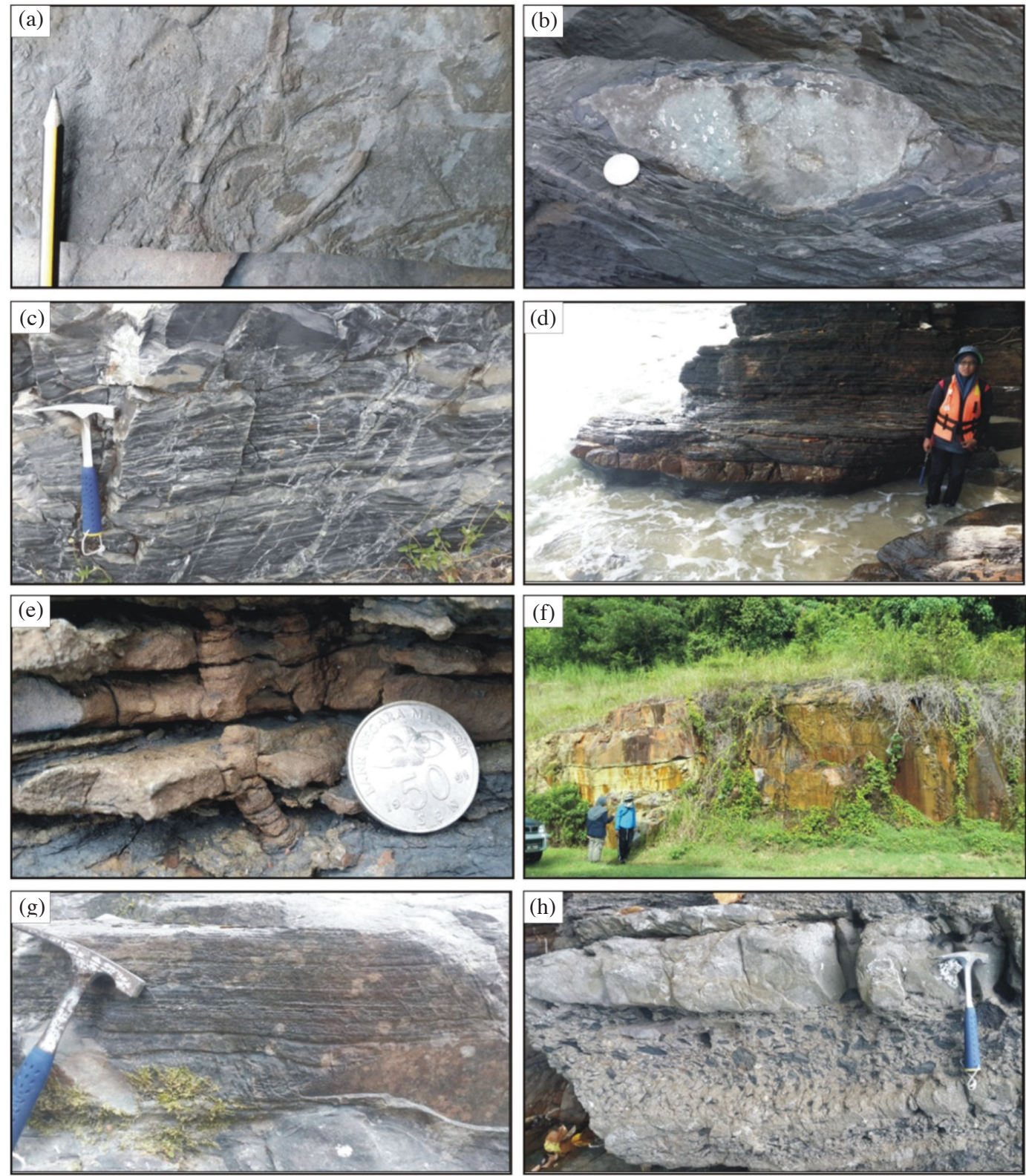

RAJAH 2. a) Kesan korekan Planolites isp., b) Pebel batu kapur yang membentuk struktur batu jatuh dalam lapisan batu lumpur di Tanjung Mali, c) Fasies heterolitik di Tanjung Lembung, d) Fasies selang lapis nipis batu lumpur, batu lodak dengan batu pasir di Pulau Singa Besar, e) Fosil Surih Arenicolites isp., f) Singkapan fasies batu pasir tebal di sekitar Bukit Tekoh, g) Lapisan batu pasir berlaminasi di Durian Perangin dan h) Batu pasir berklasta dengan struktur koyakan lumpur pada dasar lapisan

dengan hakisan bahagian dasar lapisan. Klasta batu pasir, kuarzit dan batu lumpur yang bersaiz besar jelas kelihatan bersama-sama dengan butiran bersaiz pasir. Fasies ini hanya dijumpai di Tanjung Genting dan Pulau Singa Besar.

Tafsiran Fasies ini ditafsirkan terendap dalam sekitaran berarus yang sangat kuat yang membolehkan sedimen kasar terangkut serta menghakis lapisan di bawahnya (Reading 1986). Kehadiran batu pasir berisihan sangat buruk yang membentuk fasies ini menunjukkan arus seretan bukanlah proses yang menyebabkan fasies ini terbentuk. Bentuk setiap butiran sedimen yang membentuk fasies ini mempunyai kebulatan yang rendah yang menunjukkan pengangkutan sedimen tidak jauh.

\section{F10 - FASIES KONGLOMERAT}

Fasies konglomerat ini terdiri daripada lapisan konglomerat sokongan butiran. Tebal lapisan adalah antara 15 hingga $50 \mathrm{~cm}$ dan saiz klasta berjulat antara 0.5 hingga $2 \mathrm{~cm}$. Klasta yang terdapat pada batuan fasies ini terdiri daripada pecahan batu pasir dan batu lumpur Kebanyakan klasta yang dicerap mempunyai kebulatan dan kesferaan yang sederhana. Fasies konglomerat ini dijumpai pada singkapan di sebelah barat bahagian selatan Pulau Ular.

Tafsiran Batuan konglomerat terdiri daripada sedimen klastik yang sangat kasar dan secara umumnya mempunyai asingan yang baik. Oleh itu fasies ini terbentuk melalui proses endapan melalui arus seretan yang sangat kuat 
(Nichols 2009). Kebanyakan klasta konglomerat ini telah mengalami jarak pengangkutan yang sederhana berdasarkan bentuk klastanya yang berkebulatan dan kesferaan yang sederhana.

\section{SEKUTUAN FASIES}

Sekutuan fasies adalah kumpulan fasies yang secara umumnya terendap di sekitaran pengenapan yang sama (Tucker 2003). Analisis sekutuan fasies dilakukan bagi menentukan sekitaran pembentukan kumpulan fasies berdasarkan hubungan antara fasies yang dikenal pasti. Daripada kajian ini, jujukan Formasi Singa telah dibahagikan kepada empat sekutuan fasies, iaitu SF-A, SFB, SF-C dan SF-D.

\section{SEKUTUAN FASIES A (SF-A)}

Sekutuan Fasies A (SF-A) dominan dengan fasies batu lumpur tebal (F1) dan batu lumpur berpebel (F2). Fasies lain seperti fasies batu pasir tebal (F5) juga boleh ditemui dalam sesetengah bahagian dalam sekutuan fasies ini (Rajah 3). SF-A boleh dijumpai di sekitar Pulau Tepor, Pulau Kentut Kecil, Pulau Beras Basah, Tanjung Sawa dan Tanjung Hantu. Kewujudan fasies F5 di antara fasies F1 dan F2 yang termendap secara ampaian di kawasan tenang menunjukkan kawasan pengendapan ini boleh berubah kepada keadaan yang bertenaga tinggi yang boleh membentuk fasies F5. Kehadiran arus bertenaga tinggi ini ditafsirkan dibentuk oleh ribut yang membawa sedimen bersaiz pasir ke kawasan yang tenang dan akhirnya membentuk jujukan sekutuan fasies SF-A. Oleh itu, SF-A ditafsirkan terbentuk di kawasan luar pesisir di sekitaran laut cetek. Sekitaran luar pesisir merupakan kawasan yang terletak di bawah dasar gelombang ribut (SWB). Sekitaran ini mempunyai kawasan yang tenang dan boleh dipengaruhi oleh arus semasa keadaan ribut yang besar.

\section{SEKUTUAN FASIES B (SF-B)}

Sekutuan Fasies B dominan dengan selang lapis batu lumpur, batu lodak dan batu pasir (merupakan fasies F3 dan F4), batu lumpur tebal (F1) dan batu pasir tebal (F5) (Rajah 3). Jujukan batuan yang berselang lapis ini ditafsirkan dalam sekitaran laut cetek yang dipengaruhi oleh ribut (Dashtgard et al. 2012). Beberapa jujukan yang sama turut ditemui pada beberapa formasi batuan di kawasan lain seperti Formasi Bakken (Angolo \& Buatois 2012) dan Formasi Yolde (Sarki Yondoka et al. 2015). Kesemua jujukan ini ditafsirkan terbentuk di zon peralihan antara muka pesisir dan luar pesisir atau atas luar pesisir. Zon peralihan antara luar pesisir dan muka pesisir merupakan satu zon berkeadaan tenang dan berupaya mengendapkan sedimen yang terampai seperti lumpur dan pada masa yang sama menerima aktiviti arus secara berkala bergantung kepada keadaan cuaca. Bahagian atas zon ini dibatasi oleh satu sempadan yang dipanggil dasar gelombang cuaca baik (FWWB), manakala bahagian bawah pula dibatasi oleh sempadan yang dikenali sebagai dasar gelombang ketika ribut (SWB). Jujukan ini boleh dijumpai di kebanyakan lokaliti kawasan kajian terutamanya di kawasan pulaupulau kecil di barat daya Langkawi, Tanjung Mali dan Bukit Batu Kulat.
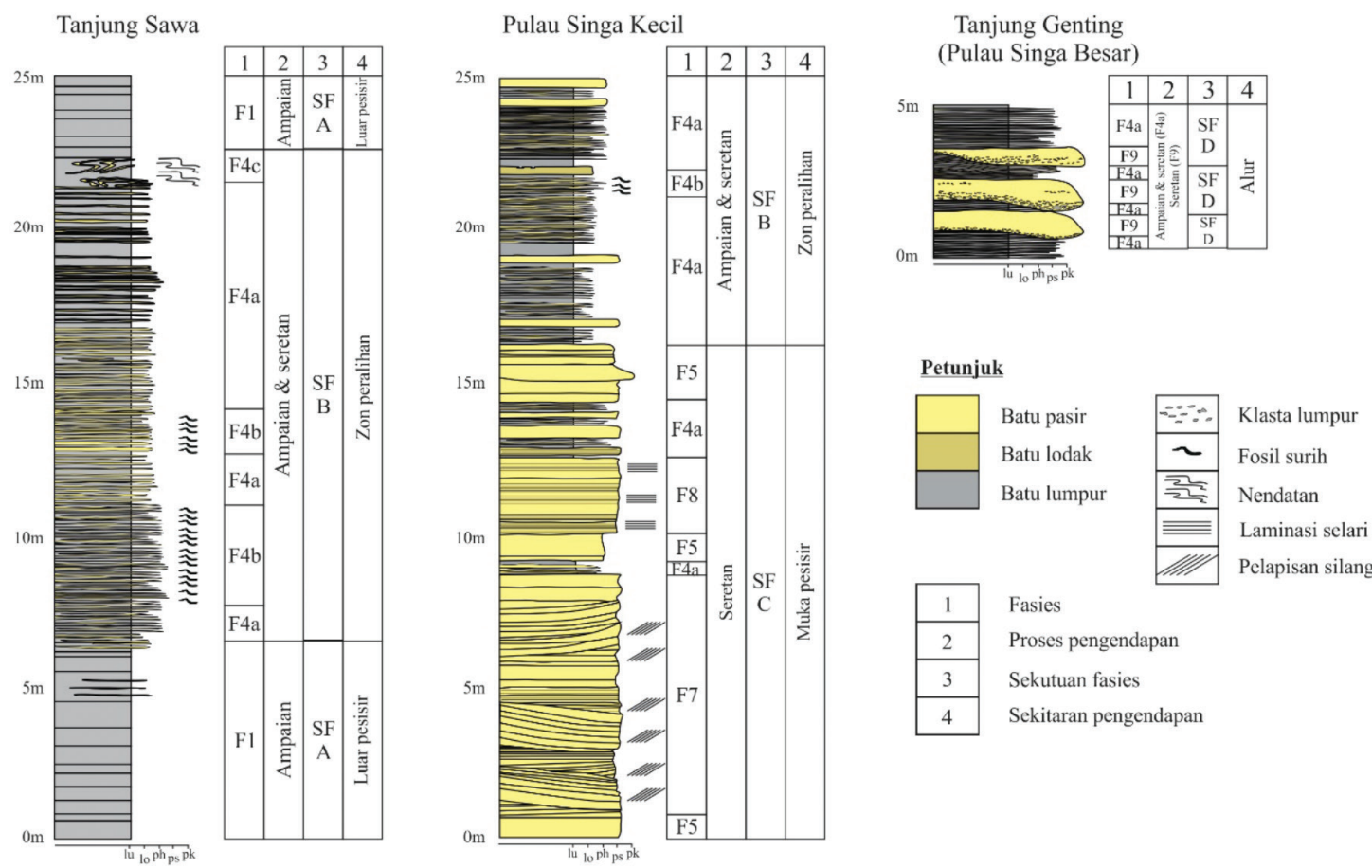

RAJAH 3. Log sedimen jujukan batuan Formasi Singa di Tanjung Sawa, Pulau Singa Kecil dan Tanjung Genting (Log tidak mewakili keseluruhan jujukan Formasi Singa) 


\section{SEKUTUAN FASIES C (SF-C)}

Sekutuan Fasies C terdiri daripada jujukan yang dominan dengan batuan bersaiz pasir. Fasies yang dominan dalam sekutuan ini ialah fasies batu pasir tebal (F5), batu pasir berpelapisan silang (F7) dan batu pasir berlaminasi selari (F8). Batuan berbutir halus seperti batu lumpur juga boleh dijumpai di dalam jujukan ini sebagai lapisan yang nipis dan hadir berselang lapis dengan batu pasir dalam fasies F4. Jujukan lengkap bagi sekutuan fasies ini boleh dijumpai pada singkapan di Pulau Singa Kecil (Rajah 3). Pada Singkapan tersebut, bahagian paling bawah jujukan didominasi oleh fasies F7 dan ditindih oleh fasies F8. Sedikit fasies F5 boleh diperhatikan di antara fasies F7 dan F8. Sekutuan Fasies C ditafsirkan terbentuk dalam subsekitaran muka pesisir di sekitaran laut cetek. Kewujudan jujukan lapisan batu pasir yang tebal menunjukkan sekutuan fasies ini terbentuk pada sekitaran yang cetek dengan arusnya lebih deras. Batu pasir berpelapisan silang yang terdapat dalam fasies ini ditafsirkan sebagai morfologi beting yang boleh terbentuk dalam sekitaran ini.

\section{SEKUTUAN FASIES D (SF-D)}

Sekutuan fasies D terdiri daripada fasies batu pasir berklasta (F9) dan fasies selang lapis batu lumpur, batu lodak serta batu pasir (F4) dan batu pasir tebal (F5) (Rajah 3). Jujukan ini membentuk jujukan yang menghalus ke atas dengan fasies yang berbutir kasar (F9) boleh diperhatikan pada bahagian bawah jujukan dan ditindih oleh fasies yang lebih halus (F4 dan F5). Klasta lumpur yang terdapat dalam fasies F9 ini ditafsirkan sebagai struktur koyakan lumpur, terbentuk apabila lapisan lumpur dikoyakkan oleh hakisan arus dan seterusnya diangkut dan diendapkan bersamasama sedimen lain. Fasies F9 ini ditindih oleh fasies F5 yang terbentuk melalui proses ampaian dan arus seretan yang sering berulang-ulang. FS-D ini ditafsirkan berlaku dalam alur di zon peralihan kerana sekutuan ini banyak ditemui bersebelahan dengan SF-B. Jujukan Sekutuan Fasies D ini boleh dijumpai di Tanjung Genting dan Pulau Singa Besar.

\section{MODEL PENGENDAPAN}

Rajah 4 menunjukkan model sekitaran pengendapan laut cetek dengan pengaruh glasier yang dihasilkan berdasarkan kajian yang dilakukan. Sekitaran laut cetek boleh dibahagikan kepada beberapa zon berdasarkan pengaruh dasar gelombang semasa cuaca tenang (FWWB) dan ketika ribut (SWB) yang menjadi faktor penting dalam menjadikan keadaan di sekitaran laut cetek berbeza di pelbagai kawasan. Kawasan yang terletak di bawah kedalaman SWB dikenali sebagai zon luar pesisir yang merupakan sekitaran yang sentiasa tenang dan terdiri daripada lumpur yang dominan (SF-A). Zon peralihan terletak di antara FWWB dan SWB, yang mana sekitaran ini berada dalam keadaan tenang semasa cuaca tenang, tetapi berarus semasa ribut. Oleh itu selang lapis antara lumpur, lodak dan pasir boleh terendap di zon ini (SF-B). Zon muka pesisir ialah kawasan yang berada di bawah zon pasang surut hingga ke bahagian atas FWWB. Kawasan ini sentiasa terkesan dengan aktiviti gelombang arus dari permukaan, menyebabkan sedimen bersaiz pasir lebih banyak terendap di sini (SF-C). Endapan alur pula membentuk SF-D dan terbentuk pada zon transisi.

\section{KESIMPULAN}

Formasi Singa terdiri daripada batu lumpur yang sangat dominan, berselang lapis dengan batu lodak, batu pasir dan juiga sedikit unit konglomerat. Berdasarkan litologi, ketebalan, struktur sedimen serta fosil dan fosil surih yang ada, jujukan Formasi Singa boleh dibahagikan kepada 10 jenis fasies. Hubungan antara fasies membentuk 4 sekutuan fasies dan ditafsirkan Formasi Singa telah teredap di sekitaran luar pesisir, transisi muka pesisir-luar pesisir, muka pesisir dan juga alur lautan cetek. Sekitaran laut cetek ini terletak di kawasan beriklim sejuk dan terdapat ais apung di sekitaran ini yang akhirnya menghasilkan unit batu lumpur berpebel.

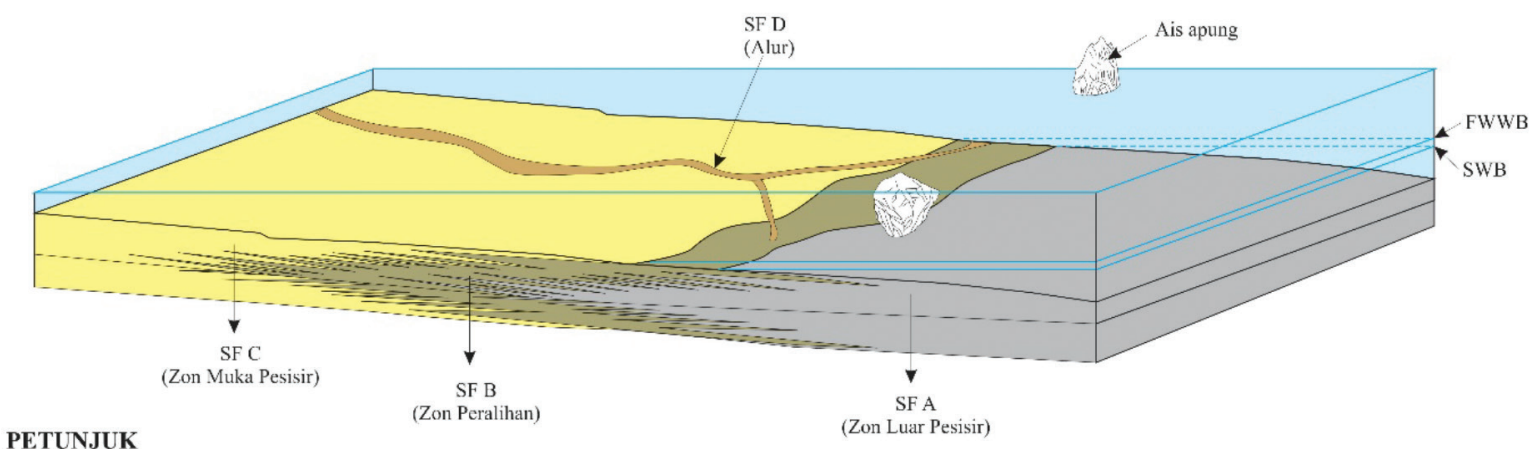

PETUNJUK

Endapan konglomerat dan pasir Endapan pasir dominan
Endapan selang lapis lumpur, lodak dan pasir Endapan lumpur dominan
FWWB $=$ Dasar gelombang semasa tenang

SWB $=$ Dasar gelombang semasa ribut 


\section{PENGHARGAAN}

Terima kasih diucapkan kepada Universiti Kebangsaan Malaysia kerana menyediakan kemudahan prasarana terutamanya peralatan makmal di Pusat Penyelidikan Langkawi, Kampus Tuanku Abdul Halim Mu'adzam Shah, Langkawi dan juga makmal di Fakulti Sains dan Teknologi, kampus Bangi. Penyelidikan berkenaan Formasi Singa ini telah dibiayai oleh projek penyelidikan Arus Perdana (AP-2014-007) dan FRGS/2/2014/ STWN06/UKM/01/1.

\section{RUJUKAN}

Ahmad Jantan. 1973. Stratigraphy of the Singa Formation (Upper Paleozoic) in the Southwestern part of Langkawi Island Group, West Malaysia. Tesis Sarjana Sains Universiti Malaya (tidak diterbitkan).

Angulo, S. \& Buatois, L.A. 2012. Integrating depositional models, ichnology, and sequence stratigraphy in reservoir characterization: The middle member of the DevonianCarboniferous Bakken Formation of subsurface southeastern Saskatchewan revisited. American Association of Petroleum Geologists Bulletin 96(6): 1017-1043.

Che Aziz Ali \& Tanot Unjah. 2011. The importance of geological heritage resources in land use planning: Experience from Langkawi Geopark. Planning Malaysia: Conservation with development: Focus on Langkawi. Petaling Jaya: Malaysian Institute of Planners. hlm. 55-82.

Collinson, J.D. \& Thompson, D.B. 1982. Sedimentary Structures. London: George Allen \& Unwin.

Dashtgard, S.E., MacEachern, J.A., Frey, S.E. \& Gingras, M.K. 2012. Tidal effects on the shoreface: Towards a conceptual framework. Sedimentary Geology 279: 42-61.

Frey, R.W. \& Pemberton, S.G. 1985. Biogenic structures in outcrops and cores. I. Approaches to ichnology. Bulletin of Canadian Petroleum Geology 33(1): 72-115.

Gobbett, D.J. 1973. Upper Paleozoic. Dlm. Gobbett, D.J \& Hutchinson, C.S. (pnyt). Geology of the Malay Peninsular. New York: Wiley-Interscience.

Jones, C.R. 1981. Geology of Perlis, North Kedah and the Langkawi Islands. Geological Survey of Malaysia District Memoir 17.

Klein, G. deV. 1977. Clastic Tidal Facies. Champaign, Illinois: Continuing Education Publication Company (CEPCO). hlm. 148.

Metcalfe, I. 1986. Late Palaeozoic palaeogeography of Southeast Asia: Some stratigraphical, palaeontological and palaeomagnetic constraints. GEOSEA V Proceesings Vol. 1 Geological Society of Malaysia Bulletin 19: 153-164.

Metcalfe, I. 1984. Stratigraphy, palaeontology and palaeogeography of the Carboniferous of Southeast Asia. Mémoires de la Société géologique de France 147: 107-118.

Mohd Shafeea Leman. 2004. Cold-water brachiopods of Sungai Itau and Kilim, Langkawi and their heritage values. Dlm. Warisan Geologi Malaysia - Kerangka Teori dan Penilaian Geowarisan. Bangi. Institut Alam dan Pembangunan (LESTARI). hlm. 207-218.

Mohd Shafeea Leman. 2000. Langkawi Dropstones: Outstanding glacioneic sedimentological features in Malaysia. Dlm. Ibrahim Komoo \& H.D. Tjia (pnyt). Warisan Geologi Malaysia - Pembangunan Sumber untuk Pemuliharaan dan
Pelancongan Tabii. Bangi. Institut Alam dan Pembangunan (LESTARI). hlm. 59-81.

Mohd Shafeea Leman. 1997. The age and paleobiogeography of brachiopod fauna discovered in pebbly mudstone at Kilim, Langkawi. Bulletin of the Geological Society of Malaysia 40: 233-240.

Mohd Shafeea Leman. 1996. The occurrences of brachiopods from pebbly mudstone near Kilim, Langkawi: Their age, paleobiogeography and paleoclimatic implication. Warta Geologi 22(2): 100-102.

Nichols, G. 2009. Sedimentology and Stratigraphy. Edisi Ke-2. Oxford. Wiley-Blackwell.

Pattison, S.A.J., Ainsworth, R.B. \& Hoffman, T.A. 2007. Evidence of across-shelf transport of fine-grained sediments: Turbidite-filled shelf channels in the Campanian Aberdeen Member, Book Cliffs, Utah, USA. Sedimentology 54: 1033-1063.

Reading, H.G. 1986. Sedimentary Environments and Facies. Edisi Ke-2. Oxford. Blackwell Scientific Publications.

Reineck, H.E. \& Singh, I.B. 1975. Depositional Sedimentary Environment. Berlin: Springer-Verlag.

Reineck, H.E. \& Wunderlich, F. 1968. Classification and origin of flaser and lenticular bedding. Sedimentology 11: 99-104.

Ridd, M.F. 2013. A Middle Permian-Middle Triassic accretionary complex and a Late Triassic foredeep basin: Forerunners of an Indosinian (Late Triassic) thrust complex in the Thailand-Malaysia border area. Journal of Asian Earth Sciences 76: 99-114.

Sarki Yandoka, B.M., Abu Bakar, B.M., Wan Hasiah Abdullah, Maigari, A.S., Mohammed Hail Hakimi, Adegoke, A.K., Shirputda, J.J. \& Aliyu Abdulkarim. H. 2015. Sedimentology, geochemistry and paleoenvironmental reconstruction of the Cretaceous Yolde formation from Yola Sub-basin, Northern Benue Trough, NE Nigeria. Marine and Petroleum Geology 67: 663-677.

Stauffer, P.H. \& Lee, C.P. 1986. Late Paleozoic glacial marine facies in Southeast Asia and its implications. Bulletin of the Geological Society of Malaysia 20: 363-397.

Stauffer, P.H. \& Manjit, N. 1981. Late Paleozoic Tilloid of Malaya, Thailand and Burma. Dlm. Hanbrey, M.J. \& Harland, W.B. (pnyt). Earth's pre-Pleistocene Glacial Records. Cambridge: Cambridge University. hlm. 331-337.

Tantiwanit, W., Raksaskulwong, L. \& Mantajit, N. 1983. Stratigraphy and correlation. Dlm Proceeding of the Workshop on Stratigraphy Correlation of Thailand and Malaysia, Volume 1. Technical Papers. Geological Society of Thailand and Geological Society of Malaysia. hlm. 96-104.

Tucker, M.E. 2003. Sedimentary Rocks in the Field. Edisi Ke-3 West Sussex: John Wiley \& Sons Ltd.

Ueno, K., Ejima, M., Kamata, T., Charoentitirat, T. \& Sardsud, A. 2005. Stratigraphy and sedimentary cycle of the Permian Kaeng Krachan Group of Phi Phi Island, southern Thailand. International Conference on Geology, Geotechnology and Mineral Resources of Indochina (GEOINDO 2005). Khon Kaen University. hlm. 555-557.

Weiss, R. \& Bahlburg, H. 2006. A note on the preservation of offshore tsunami deposits. Journal of Sedimentary Research 76(12): 1267-1273

Wheatcroft, R.A. 2000. Oceanic flood sedimentation: A new perspective. Continental Shelf Research 20: 2059-2066. 
Mohamad Hanif Kamal Roslan, Che Aziz Ali* \& Kamal Roslan Mohamed

Pusat Penyelidikan Langkawi

Institut Alam Sekitar dan Pembangunan (LESTARI)

Universiti Kebangsaan Malaysia

43600 Bangi, Selangor Darul Ehsan

Malaysia
*Pengarang untuk surat-menyurat; email: che@ukm.edu.my

Diserahkan: 10 Mei 2016

Diterima: 22 September 2016 